\title{
A text become provisional: revisiting the capital of the ruins
}

Article

Accepted Version

Davies, W. (2017) A text become provisional: revisiting the capital of the ruins. Journal of Beckett Studies, 26 (2). pp. 169-187. ISSN 1759-7811 doi:

https://doi.org/10.3366/jobs.2017.0201 Available at https://centaur.reading.ac.uk/85384/

It is advisable to refer to the publisher's version if you intend to cite from the work. See Guidance on citing.

To link to this article DOI: http://dx.doi.org/10.3366/jobs.2017.0201

Publisher: Edinburgh University Press

All outputs in CentAUR are protected by Intellectual Property Rights law, including copyright law. Copyright and IPR is retained by the creators or other copyright holders. Terms and conditions for use of this material are defined in the End User Agreement.

\section{www.reading.ac.uk/centaur}

\section{CentAUR}

Central Archive at the University of Reading

Reading's research outputs online 


\title{
A Text Become Provisional: Revisiting The Capital of the Ruins
}

\author{
William Davies
}

The Capital of the Ruins (hereafter TCotR) remains an often cited but seldom analysed text in the Beckett canon. Written for Raidió Éireann in 1946 (renamed Raidió Teilifís Éireann in 1961; hereafter $\mathrm{RTE}^{1}$ ) following his work with the Irish Red Cross in the war-torn Saint-Lô, the text is often used to point towards Beckett's recognition of a 'humanity in ruins' and a 'universe become provisional' (278) after the war. ${ }^{2}$ Though remaining a minor piece in the Beckett oeuvre overall, TCotR forms an important part of Beckett's war-time narrative and, given that its more dramatic phrases are often deployed to give flourish to a critical conclusion, a focus on the text itself remains productive.

The text of $T \operatorname{CotR}$ and its introductory details have appeared in a number of guises. Discovered in the archives of RTÉ in 1983, the typescript is signed by Beckett with the date 10 June 1946 and contains edits from multiple origins, as confirmed by Beckett after S. E. Gontarski sent him a photocopy $(1995,286)$. The text has been published with introductions by Eoin O'Brien in The Beckett Country (1986), by Dougald MacMillan in As No Other Dare Fail (1986) and As The Story Was Told (1990), and by S. E. Gontarski in Collected Short Prose (1995; hereafter CSP), all with various incorporations or exclusions of the typescript edits, and all with different information on the text's context and possible broadcast. It is clear that a definitive edition of the text is necessary. ${ }^{3}$

In response to Gontarski's assertion that 'Beckett's exact prose ought to be recovered and retained wherever possible' (Gontarski, 1995, 286), Phyllis Gaffney (1999a) accounts for a number of the edits that are included in the various publications, as well as offering speculation on the text's composition and broadcast. However, given the time between Gaffney's work and the surge in availability of resources related to Beckett in the last decade and a half, a re-engagement with the text is necessary. This essay attempts to correct any further errors or absences of information that may have arisen in regard to TCotR. Along with offering the grounds for a definitive edition of the text, this essay also engages with some of the finer points of its content and context that have remained under-explored. Enabled in part by the reintroduction of phrases omitted in publication, this essay considers the extent to which the text produces a more specific engagement with the politics and attitudes that Beckett returned to in Ireland in the aftermath of neutrality.

\section{Broadcast}

In The Beckett Country, O'Brien writes that 'On 10 June 1946, Samuel Beckett [...] wrote an account of the Irish Hospital for broadcasting to the Irish people on Radio Éireann' (333). MacMillan takes this date to be indicative of its broadcast: 'The following script published here for the first time, was read by Beckett on Radio Erin [sic] on 10 June, 1946' (MacMillan, 1990, 84). As Gontarski shows, Beckett's involvement with the broadcast is undocumented with neither fee cards or correspondence included in the RTé archives (CSP, 286). The date on the typescript is far more likely the date of submission since it is repeated in another hand in the top right corner of the first typescript page, likely to signify receipt of the script.

On the question of broadcast, Gaffney locates a 'Paris Newsletter' RTÉ segment running throughout the summer of 1946. On 10 June, there is a 'Letter from Paris' listed in the schedule which Gaffney speculates could have been Beckett's text (1999a, 260). However, if these 'newsletters' were submissions or broadcasts from Paris to Dublin, correspondences from Beckett between 25 April and 19 June place him in Dublin during this period (2012a, 29-37). 
Though Beckett may have been commissioned to write the text whilst in Paris in early 1946, it seems unlikely that it would have been included in this segment given that Beckett was in Dublin on the date on the typescript.

The lack of RTÉ records remains the clearest indication that the text was not broadcast. The reasons for this will likely remain unknown. Gaffney's notion that Beckett's censored status played a role is possible given the all too recent neutrality censorship; ${ }^{4}$ one would suspect, though, that Beckett's censored status would have been dealt with at the point of commission. There is the possibility that the text was ultimately dismissed by the RTÉ talks organiser Roibeard ó Faracháin who, in 1940, had 'declared [his] commitment' to represent the "Real Ireland of Today" - the Catholic, pious, rural, and parish-based one' in his role at the state radio station (Wills, 2007, 353). That Ó Faracháin saw the text is evidenced by his initials on the first page of the typescript $(C S P, 286)$. As will be shown, the piece contains various critiques directed at the prospective listeners and towards attitudes in Ireland more broadly; if picked up by someone like Faracháin, these could have been enough for the piece to be rejected.

\section{Archive}

The text's archival existence also requires clarity. Found in the RTÉ archive in 1983, the text was shown by Seán Ó Mórdha to O’Brien (O’Brien, 385) who published the text 'in full incorporating all the manuscript changes in Beckett's hand' (333). The original remains part of the RTÉ archive holding, now managed by University College Dublin. After its discovery, photocopies of the text were made of which two are accounted for. The first was sent by John Calder's secretary Anna Menmuir to Barney Rosset on 7 November 1986 along with a copy of 'neither', now held at Boston College. ${ }^{5}$ The second is found in the Beckett International Foundation archives at the University of Reading (UOR MS 2905) which was part of a donation made by Beckett in 1987. Gaffney cites another copy amongst the papers of the late Mary Crowley, however correspondence with Eoin O'Brien and Mary O'Doherty, the archivist managing Miss Crowley's papers at the Royal College of Irish Surgeons, suggest that this is not the case. In an interview with Deirdre Bair, Miss Crowley does not mention the script (Bair, 1972, HRHRC MS-5124, Container 1.6) and, until further evidence can be found, this copy should be discounted or considered lost.

Amongst the two extant copies, the UOR photocopy is unique as it has been edited in red pen at some point after the copy was made. I suggest that this version is the one sent to Beckett by Gontarski in 1983 after the initial discovery of the text (CSP, 286). In this copy, most of the changes or deletions are attended to with a large red 'STET', including a number of changes that have appeared in publication. Yet it is not this copy that informs the CSP version, as first indicated by Gaffney who notes the variants introduced in Macmillan's edition alongside some of those listed below (1999a, 265) - in particular, the use of 'human conditions' instead of 'human condition' and 'cures' instead of 'cured'. I concur with the UOR catalogue for the holding and with Gaffney that all of the red pen edits are Beckett's. As such, I suggest that this UOR holding represents the 'final' copy of TCotR and, if Beckett's editing hand is to be preserved, it is this which should serve as a definitive edition of the text when it comes to republication.

\section{Text}

Beckett's 'STET' identifies what is to be restored or retained:

1. Restores the deletion in: 
The floors, there where the exigencies of hygiene are greatest, are covered with linoleum. (UOR MS 2905. Leaf 1; deletion observed in CSP, 275)

2. Restores the deleted half in:

The supply of electric current, for purposes both of heat and of power, leaves nothing to be desired, though painstakingly anonymous attempts were made, in this country, as recently I think as last winter, to prove the contrary. (UOR MS 2905. Leaf 1; deletion observed in CSP, 276)

3. The phrase 'no offense [sic] meant' is restored in:

The medical, scientific (no offense meant), nursing and secretarial staff are Irish [...]. (Leaf 1; deletion observed in CSP, 276).

4. The deleted phrase is restored in:

Among such ambulant cases the number is large of those ${ }^{\text {a large number are }}$ suffering (Leaf 2; alternative phrase included in CSP 276)

5. The three commas are removed from the following:

I suspect that our pains were those inherent in the simple and necessary and yet so unattainable proposition that their way of being we, was not our way, and that our way of being they, was not their way. It is only fair to say that many of us had never been abroad before. (Leaf 3; commas included in CSP, 277)

The only unaddressed edit appears at the beginning of the piece:

6. The addition of 'left' by a 'third party' is retained in:

There is not enough linoleum left in France. (Leaf 1; addition not included in CSP, 275)

The final example is important for the question of interventions by other hands since the word does not receive a 'STET'. Despite the forty-years between composition and his encounter with it in the 1980s, Beckett appears to give his full attention to this piece (he adds the circumflex to the 'o' in Saint-Lô on almost every occasion and attends to both punctuation and content). As such, if we are to observe Beckett's editing to the piece and are to assume he spent enough time to consider each addition, deletion or alteration, the addition of 'left' should be observed.

The fifth passage above also signifies that the text was more fully edited than previously thought. The added commas suggest that the text may have been prepared for broadcast since the punctuation functions as elocutionary rather than grammatical pauses. A comparison is found in the addition of commas to the phrase 'When I reflect now on the recurrent problems of what, with all proper modesty, might be called the heroic period' (Leaf 3) which serve both an elocutionary and grammatical function. They are retained in Beckett's edit. ${ }^{6}$

This removal of elocutionary commas also signifies the demarcation of $T C \operatorname{Cot} R$ as a prose piece rather than a work for radio, a status subsequently made concrete by its inclusion in a 
'complete prose' collection. Nevertheless, the text occupies a liminal space between the two forms and its existence within the prose section of the oeuvre should not preclude a radiophonic analysis of the text. What must also be acknowledged is how the text contains an address to its potential Irish audience within a chilling recognition of the devastation of a town 'bombed out of existence in one night' $(C S P, 277)$. It is to this that I now turn.

\section{Irish Neutrality}

In his introduction to the text, Macmillan briefly suggest its potential political implications by situating the text first as a rebuttal to 'Dublin disparagement' of the project and then as 'a rare piece of polemic attempting to correct Irish parochialism' $(1990,84)$. Though Gaffney is right to point out that MacMillan's sources for Irish criticism of the Saint-Lô project are unclear, a recurring scepticism towards the intentions of war reportage in Europe did accompany coverage of the war in the Irish press. With this and the conditions of Ireland's war-time neutrality in mind, there is more to be said on the piece's position as a 'polemic' than has previously been considered.

Whilst 'parochialism' here inevitably implies Ireland's war-time neutrality when reading the text, it is important to emphasise that it is not Ireland's neutrality that Beckett rejects so much as how neutrality was enforced through political and cultural censorship and a propaganda policy that emphasised insularity and protectionism against the prospect of international warfare.

Neutrality itself is unlikely to have shocked Beckett; despite critiques, he remained astutely aware of Ireland's politics prior to the war even when abroad. Eamon de Valera made clear Ireland's neutral position in international conflicts as early as the 1936 Italian invasion of Abyssinia. This was reaffirmed by Ireland's membership of the Non-Intervention Committee during the Spanish Civil War in 1937, a conflict to which Beckett played close attention via Nancy Cunard. ${ }^{7}$ The policy was formally declared again on the outbreak of war in September 1939 and the necessity of a neutral stance would have been of little surprise to even the surliest of critics of the de Valera government. ${ }^{8}$ With a minute defence force and a still emerging independent economy, Ireland's intervention into the war would not only have been a political miscalculation for its connection to Britain and the Allies, it also would have likely crippled the country financially and militarily.

Despite neutrality, Ireland's war years were far from peaceful. The nation suffered severe food shortages, declining employment and divisions between those who saw neutrality as a declaration of sovereignty and those who viewed the fight against fascism as one of moral importance. The latter view was often coloured as a distinctly 'European' mind-set in certain nationalist quarters and gave rise to a renewed tension between the conceptions of 'Ireland' and 'Europe' within the country. As Clair Wills (2007) has shown in her key study of Irish neutrality, cultural sovereignty was as much in question as was political independence (265). Censorship was at the heart of this debate.

The use of censorship as part of the promotion of a particular cultural nationalism lies at the heart of Beckett's rejection of the Ireland of his formative years, evidenced by his attacks in letters and critical pieces of the 1930s. Censorship also remained a key tool in enforcing the neutrality policy. Beckett's much hated mode of government intervention came in to immediate effect: radio, film and published writings were all subject to censorship, particularly those involving references to one side of the conflict triumphing in Europe or external attempts to challenge neutrality (particularly from Britain). Though there were some critics of the military implications of neutrality, it was the manner in which neutrality was framed, enforced and encouraged that provoked criticisms and concerns over isolationism and narrow-mindedness from a number of often particularly culturally minded figures. Elizabeth Bowen reported to the 
British Ministry of Information in 1940 that Ireland was experiencing a "claustrophobia and restlessness' that stunted her notion of progress or modernisation. She saw the 'virtual closing of the Irish Channel' as 'equivalent, for the more intelligent and Europeanly-minded people in Dublin and throughout Ireland, to a closing of the Burma Road' (1940; qtd. in Fisk, 409). There were clear class and status dimensions to these characterisations of neutrality. By contrast, the propaganda around the policy itself appears to have been broadly successful amongst the general population. As the politician Herbert Shaw identified at the time, neutrality even produced surprising cross-party support between 'the ranks of de Valera's supporters', 'the Cosgrave Party' and 'even former Unionists', all of whom 'held no other policy to be possible' (1941; qtd in Fisk, 1983, 413). Even Bowen soon acknowledged the necessity of neutrality in Ireland:

It may be felt in England that Ireland is making a fetish of her neutrality. But this assertion of her neutrality is Eire's first free self-assertion: as such alone it would mean a great deal to her. Eire (and I think rightly) sees her neutrality as positive, not merely negative. She has invested her self-respect in it. [...] One air raid on an Irish city would produce a chaos which, in the long run, England would have to cope. (1940; qtd in Fisk, 412.)

Sovereignty remained at the heart of neutrality and the de Valera government saw this as much to do with cultural independence as it did political or military strength. This was achieved through an intensification of the Irish cultural nationalism that Beckett had so staunchly rejected in texts such as 'Censorship in the Saorstat' and 'Recent Irish Poetry' (1983). This was typified in de Valera's 1943 Saint Patrick's Day speech in which he spoke of an 'ideal Ireland'

whose countryside would be bright with cosy homesteads, whose fields and villages would be joyous with the sounds of industry, with the romping of sturdy children, the contests of athletic youths and the laughter of comely maidens[.] (17 March 1943; qtd. in Fisk, 417)

Quite distinct from the cultural relations that the likes of Bowen championed during the period, this vision was maintained throughout the war and beyond. It is to this climate that Beckett returned in 1945. He appears to have soon harboured concerns that insularity had become part of daily life, apparently remarking at the time ' $[\mathrm{m}] \mathrm{y}$ friends eat sawdust and turnips while all Ireland safely gorges' (Bair, 1978, 287). Though the relative wealth of Beckett's family in Foxrock must be kept in mind (food shortages were a reality in Ireland during the war), it is clear that Beckett saw a firm disparity between conditions in Ireland and those on the continent.

\section{'Obscure tensions'}

Beckett returned to Ireland on or around 16 April 1945. Though he did not experience the full extent of neutrality in Ireland, the censorship policy was not lifted until the following month. The wider issue that Beckett returned to was the aftermath of neutrality and the revelations of the events of the war. Footage of devastation on the continent began to circulate more freely, as did that of concentration camps. In turn, revelations of the use of camps by the Nazis were disputed by some as Allied (specifically British) propaganda; having lost friends and Resistance colleagues to the camps, Beckett would not have been sympathetic to this pernicious yet inevitable outcome of five years of censorship and scepticism towards Allied intentions. An exchange in the Irish Times is indicative of this situation: 
On 14 May 1945 the Irish Times published a letter from a Senata Woods [...] to express the dismay at the way 'the general public doubt the truth of the articles and photographs which have been published in the leading British newspapers about the atrocities committed by the Germans in the concertation camps in Germany.' (Brown, 2015, 190)

Woods suggested an Irish delegation be sent to the camps. A reply followed on 16 May:

[i]f we are to celebrate the removal of the censorship by washing other countries' dirty linen in our public press, why not send the party of ghouls to India, China, Palestine or Russia? [...] Now that the war is over, there is a real task before us - that of building the peace. We now need to strengthen our confidence in human nature, not undermine the last tottering ruins of it. It would be more encouraging at this point to be shown the great things of which mankind is still capable; there is already too much evidence of its failings. (Wills, 399)

As Wills argues, for some this defiantly humanistic response was a mark not of decency but of the dangers of neutrality:

This wish to hold back stories of the horrors of the war was echoed by numerous journalists and commentators in the final weeks of the conflict [...]. It was the kind of attitude that seemed to confirm the complaints of people as far apart politically as Elizabeth Bowen and Francis Stuart: that neutrality had bred insensitivity and complacency. (Wills, 399) ${ }^{9}$

Such 'complacency' is recalled throughout Beckett's references to the 'human condition' in $T C$ ot $R$, suggesting that Lois Gordon's notion that the text 'exalts [...] the comfort to be drawn from the inward human capacity to surmount circumstances of the utmost gravity' (Gordon, 201) may miss the political implications that accompany Beckett's recognition of the devastation in Saint-Lô; more on this below.

As the war came to a close, press coverage of the devastation in Europe prompted a number of initiatives to produce aid projects in Europe. Saint-Lô was chosen by the Irish Red Cross after increasing coverage of its brutal bombing in the press (Gordon, 189-191). Gordon writes that ' $[\mathrm{m}]$ ost Dubliners would have been keenly aware of the devastation suffered by Saint-Lô [...]. [The Irish Times] closely documented Saint-Lô's "heartrending ordeal"” (190). Though the cause of accusations of isolation, neutrality did allow resources to be generated for this kind of charitable project.

Upon arrival in Saint-Lô, however, Beckett felt more dismayed then charitable:

We have been quite misinformed by the French Red $\mathrm{X}$ and the whole thing is disappointing. It is complicated further by all kinds of obscure tensions between the local medical crowd and the Red X people in Paris. We have the impression that the locals would like stuff, but don't want us (very reasonable attitude) [...] The apparent apathy doesn't irritate me as it does the other two [Alan Thompson and Colonel McKinney], whose reaction to the people is more less the classical anglo-saxon [sic] exasperation. It is a tune of which I am tired. (2012a, 18-19)

Nevertheless, Beckett saw out his contract until its end on 31 December 1945.

\section{'The heroic period'}


Though hardly renowned for its musicality, TCotR bears several traces of this 'tune' that tested Beckett's patience. Alongside a report of the town's near total destruction (and the optimism that it would be rebuilt within a decade), the text can be read as a serious evaluation of Irish politics from the period that suggests that the charity of the Irish Red Cross was not matched by the cultural and political attitudes which remained dominant in Ireland. This critique is best divided into 'explicit' and 'implicit' with the latter enacting a far subtler appraisal of Irish cultural and political policy.

The first 'explicit' comment follows the description of the hospital's material conditions which begins the text:

The hospital is centrally heated throughout, by means of coke. The medical, scientific, nursing and secretarial staff are Irish, the instruments and furniture (including of course beds and bedding), the drugs and food, are supplied by the Society. $(C S P, 276)^{10}$

As seen above (1.), Beckett originally wrote (and so restores) the phrase 'no offense meant' after the word 'scientific'. Gaffney identifies this phrase as Beckett's 'characteristic distancing of himself from his fellow Irishmen' (1999a, 268). Emphatically positioned after 'scientific', the phrase is surely more engaged than this, becoming an apology for the mention of the word 'scientific' in a broadcast on Irish state radio. The comment makes scientific practice commensurate with a kind of attitude and policy that is lacking and even 'offensive' in Ireland. This echoes Beckett's pre-war attack on Irish policy in 'Censorship in the Saorstat' which emphasises the scientific implications of censorship and the related attitudes to decency and contraception: 'Sterilization of the mind and apotheosis of the litter suit well together (1983, 86-87).

Recalling the apparently 'very reasonable attitude' of the French wanting Irish materials but not Irish persons, a later bracketed comment (which survives the editor's hand) explicitly mocks the insularity of recent Irish attitudes via the establishment of a difference between the 'spirit[ed]' French and the Irish 'bringing gifts'. This is enfolded into a more complex commentary on a culture of health and sustainability that formed a key aspect of Irish state policy towards the 'sick' and war-ravaged populations of Europe. Beckett draws on this in his radio script:

That the operating-theatre should be sheeted with an expensive metal, or the floor of the labour-room covered with linoleum, can hardly be expected to interest those accustomed to such conditions as the sine qua non of reputable obstetrical and surgical statistics. These are the sensible people who would rather have news of the Normans' semi-circular canals or resistance to sulphur than of his attitudes to the Irish bringing gifts, who would prefer the history of our difficulties with an unfamiliar pharmacopeia and system of mensuration to the story of our dealings with the rare and famous ways of spirit that are the French ways. (CSP, 276)

In one of the more elliptical passages (in a text that would already be a difficult listen for any audience), Beckett marries the Homeric 'bringing gifts' metaphor with the oddly academic specificity of 'Norman' ear shape and a 'resistance' to certain chemicals. Again, the text draws on a scientific lexicon to emphasise the difference between the prospective Irish listeners and their desire to hear of 'unfamiliar pharmacopeia' instead of the French community helped by the Saint-Lô project.

The text continues: 
What was important was not our having penicillin when they had none [...] but the occasional glimpse obtained, by us in them and, who knows, by them in us (for they are an imaginative people), of that smile at the human condition as little to be extinguished by bombs as to be broadened by the elixirs of Burroughes and Welcome [sic], - the smile deriding, among other things, the having and the not having, the giving and the taking, sickness and health. (Beckett, UOR MS 2905, Leaf 3; my emphasis)

Beckett's focus on the necessity of 'imagination' to introduce the Irish into this sense of a 'smile at the human condition as little to be extinguished by bombs' negates any sense of humanistic unity or collectivism in the project. That this appears to refer to divisions between the Irish and the French in the Saint-Lô project is implied in Beckett's reference to the project's administrative issues:

It would not be seemly [...] to describe the obstacles encountered in this connexion [of the Irish and the French], and the forms, often grotesque, devised for them by the combined energies of the home and visiting temperaments. $(C S P, 277)$

Beckett acquiesces, however, and acknowledges that the two had in some sense come together in the project: 'It must be supposed that [the obstacles] were not insurmountable, since they have long ceased to be of much account' $(C S P, 277)$. Given that it is implied that these difficulties were 'surmounted', the direction of Beckett's 'imaginative people' and the subsequent prospect of a 'human condition' can be read as being aimed at the prospective listeners of the text, producing a broader condemnation of appeals to 'the human condition' in lieu of the specificities of post-war reality which appeared in Ireland (and, of course, elsewhere) after the war.

As the piece draws to a close, Beckett intimates a more contemplative approach to recent history, yet it is here that he encodes an implicit commentary on the problems (as he sees them) that still dominate Irish cultural and political attitudes:

When I reflect now on the recurrent problems of what, with all proper modesty, might be called the heroic period, on one in particular so arduous and elusive that it literally ceased to be formulable, I suspect that our pains were those inherent in the simple and necessary and yet so unattainable proposition that their way of being we was not our way and that our way of being they was not their way. It is only fair to say that many of us had never been abroad before. (Beckett, UOR MS 2905, Leaf 3)

The phrase 'recurrent problems of what, with all proper modesty, might be called the heroic period' undoubtedly evokes the war and the 'heroic' effort required for rebuilding across Europe. However, this wording also contains a veiled remark on the contemporary Irish political-cultural policies when one considers that 'the heroic period' is also the subtitle to Standish O'Grady's History of Ireland: Heroic Period (1878). Mocked in Beckett's 1934 essay 'Recent Irish Poetry', O'Grady's approach to Irish history underpins much of the emphasis on national Irish culture that Beckett attacked throughout the 1930s and which, during the Second World War, was used to maintain neutrality through a repeated emphasis on national and regional sensibilities. For O'Grady, 'history' is a 'flower' of a 'heroic' kind in Ireland: 'The forefront of Irish History we find filled with great heroic personages of a dignity and power more than human' (1878, web). For Beckett, it would seem, such a rhetoric of heroism, like that of the humanistic unity, represents the 'recurring problems' that separated Irish attitudes from reality. Beckett's phrase 'the heroic period' and the surrounding passage can be reread as awash with a disdain for the veiling effects of grand narratives of history which were repeatedly 
used in neutrality propaganda and in broader Irish cultural sensibilities. ${ }^{11}$ In turn, this reading of the text shifts the otherwise apparent humanism of the final paragraph's sense that 'our condition' might be 'thought again' $(C S P, 278)$ to become a more probing critique of isolationism. The end of this piece becomes not just a treatment of the Saint-Lô tensions (which were 'not insurmountable) but an ironic representation of what Beckett terms 'our pains' (that is, the 'pains' of the potential listening Irish public) and their role in preventing a consciousness that goes beyond national, political and cultural borders.

Read in this way, TCotR becomes a commentary on the perceived implications of neutrality at the time. The text's conclusion is that tensions and difficulties in the project are symbolic of an insularity and inward facing national attitude; a result of the fact that 'many of us had never been abroad before'. Already implying a lack of cultural experience amongst the project's staff, this phrase also employs a double-meaning in its linguistic formulation: Beckett's use of 'abroad' draws on both the sense of being in a foreign country and, in what is now the more archaic sense of 'abroad', being outside or away from one's home (OED online, 2017). A subtle difference, it nonetheless indicates a certain insularity that Beckett attributes to the intended Irish listener which is encoded within a description of the Saint-Lô workforce. Beckett's choice of an 'abroad'/'home' dichotomy is worth identifying in particular when one considers its implications in one of the most discernibly 'Irish' post-war works, All That Fall. As Maddy Rooney makes her way to meet her husband, she reflects upon leaving the safety of the home environment and displays the dual meaning of the term 'abroad' more forcefully: 'It is suicide to be abroad. But what is it to be home [...]? A lingering dissolution' (Beckett, 2006, 175). ${ }^{12}$ If there is the representation of insular, even parochial attitudes in this comment then it is also worth emphasising that the tension between 'home' and 'abroad' also suggests a sense of entrapment contained within the two: in 'home' there is isolation, in 'abroad' there is the unknown. The germ of this dichotomy is seen in TCotR, however any sympathy present is reserved for a conception of 'humanity in ruins' that those who 'come home' from Saint-Lô (that is, the Irish) 'could hardly give', one that the text implies has only been discoverable upon going 'abroad'. TCotR concludes its subtle yet damning appraisal of parochialism in its final confirmation that any 'vision' or 'inkling' of 'humanity', even one 'in ruins', is to be found outside of Ireland. The impact of this, Beckett writes, will see the project remembered as 'the Irish hospital', but, crucially, '[t] hese will have been in France' $(C S P, 278) .{ }^{13}$

\section{Conclusions}

Whilst we do not have direct remarks from Beckett on Irish neutrality itself, this reading of $T C o t R$ reconfigures the text towards a more direct comment upon prevalent attitudes in Ireland at the time. Clearly admonishing the ways in which neutrality was enforced - through what is perceived to be an insular politics of censorship and the construction of a national culture and history - the text adopts a language of collective 'pains' to provoke a reconsideration of the implications for insularity and parochial positions. By pivoting upon the concept of a 'glimpse' of a 'human condition' that might be 'thought again', the text points towards the prospect of a more open national attitude, however it also critiques the complex ways that a rhetoric of heroic solidarity in Ireland (and elsewhere) served to isolate the populace and downplay the reality of the ruins in Europe. TCotR subtle critique of Irish policy rests upon an ambiguity of encoded language that simultaneously produces a legitimate, sympathetic response to the horrors of the systematic devastation of modern warfare that Saint-Lô symbolises. This technique is of particular importance for considering Beckett's other, creative work in relation to the complex cultural and political negotiations that the post-war period demanded in Ireland, France and across Europe as a whole, and it is via these supposedly minor 
texts that we can often uncover ways in which to consider the political and historical nuances of Beckett's writing as a whole.

\section{NOTES}

${ }^{1}$ As with the radio station's own conventions, 'RTÉ' will be used as short-hand in this essay for pre- and post-1961 references to the broadcaster.

${ }^{2}$ Of the handful of focused studies on the text, Phyllis Gaffney's (1999a) investigation of TCotR arise from her important study Healing Amid The Ruins (1999b). Lois Gordon (1996) views the text as indicative of Beckett's moral attitudes during the period. In a particularly sensitive analysis, John Pilling (1997) explores the text's style in relation to Beckett's other critical writings. Darren Gribben (2008) and Dúnlaith Bird (2012) see the text as particularly significant in terms of its resonance with Beckett's later work.

${ }^{3}$ As Mark Nixon and David Tucker (2015) make clear, TCotR forms an important part of Beckett's non-fiction and critical canon.

${ }^{4}$ War-time censorship of RTÉ came to an end on 11 May 1945 ('RTÉ 1940s', RTÉ online).

${ }^{5}$ I am indebted to James Little for this information.

${ }^{6}$ As Dirk Van Hulle suggests, punctuation is as vital as wording to Beckett; the discovery of the TCotR typescript is contemporaneous to the writing of Stirrings Still, a text that Van Hulle identifies as an example of Beckett's keen eye for the role of punctuation in later work (2011, 66). Stirrings Still also contains the mention of 'Darly', a near-allusion to Arthur Darley, Beckett's Saint-Lô colleague. See Van Hulle (2011) for the development of this allusion.

${ }^{7}$ See n.17 to letter from Beckett to Macgreevy, 26 April 1937 in Letters I, 488.

${ }^{8}$ Beckett had also confirmed in a letter to MacGreevy in April 1939 his intentions to go to France in the event of war, well before neutrality was declared (Beckett, 1939; qtd in Knowlson, 297).

${ }^{9}$ A. J. Leventhal was amongst the critics of this outcome of neutrality, writing in the Irish Times of the true nature of the statistics being disseminated in Ireland (Brown, 2015, 192).

${ }^{10}$ Unless the revised text is required, Gontarski's edition is referred to for quotations.

${ }^{11}$ As Andrew Gibson (2013) argues, Beckett also rejected the heroic vocabulary of post-war Gaullism. The reading in this essay does not exclude a larger commentary from Beckett upon this kind of language.

${ }^{12}$ For a use of 'abroad' that is somewhat contemporary to TCotR, see the final paragraph of 'The Expelled': 'When I am abroad in the morning I go to meet the sun, and in the evening, when I am abroad, I follow it, till I am down among the dead' $(C S P, 60)$.

${ }^{13}$ Gibson (2013) suggests that this tension between the Irish and French elements of the Saint-Lô experience has particular importance for the Franco-Irish relations that he identifies in Mercier et Camier.

\section{WORKS CITED}

Beckett, Samuel (1983), Disjecta, New York: Grove. Beckett, Samuel (1987?), The Capital of the Ruins, UOR MS 2905. 
Beckett, Samuel (1990), As The Story Was Told, Dougald Macmillan (ed.), New York: Grove. Beckett, Samuel (1995), The Complete Short Prose 1929-1989, S. E. Gontarski (ed.), New York: Grove.

Beckett, Samuel (2006), The Complete Dramatic Works, London: Faber \& Faber.

Beckett, Samuel (2009), The Letters of Samuel Becket, Volume I: 1929-1940, Martha Fehsenfeld and Lois More Overbeck (eds.), Cambridge: Cambridge University Press.

Beckett, Samuel (2012a), The Letters of Samuel Beckett, Volume II: 1941-1956, George Craig, Martha Fehsenfeld, Dan Gunn and Lois More Overbeck (eds.), Cambridge: Cambridge University Press.

Beckett, Samuel (2012b), Collected Poems, John Pilling and Seán Lawlor (eds.), New York: Grove.

Bair, Deidre (1972), 'Interview with Mary Crowley', MS-5124, Container 1.6, Harry Ransom Humanities Research Center.

Bird, Dúnlaith (2012), 'Light, Landscape and Beckett' in Angela Moorjani, Danièle de Ruyter, Dúnlaith Bird and Sjef Houppermans (eds.) Early Modern Beckett, Samuel Beckett Today / Aujourd'hui, vol. 24, pp. 239-248.

Brown, Terrence (2015), The Irish Times: 150 Years of Influence, London: Bloomsbury.

Fisk, Robert (1983), In Time of War: Ireland, Ulster and the Price of Neutrality 1939-1945, Dublin: Gill \& MacMillan.

Gaffney, Phyllis (1999a), 'Dante, Manzoni, De Valera, Beckett...? Circumlocutions of a Storekeeper: Beckett and Saint-Lô', Irish University Review, 29:2, pp. 256-280.

Gaffney, Phyllis (1999b), Healing Amid the Ruins, Dublin: A \& A Farmar.

Gibson, Andrew (2013), 'Franco-Irish Beckett: Mercier et Camier in 1945-6', Samuel Beckett: Debts and Legacies: New Critical Essay, London: Bloomsbury.

Gordon, Lois (1996), The World of Samuel Beckett, New Haven: Yale University Press.

Gribben, Darren (2008), 'Beckett's Other Revelation: "The Capital of the Ruins"', Irish University Review, 38:2, pp. 263-273.

Knowlson, James (1997), Damned to Fame, London: Bloomsbury.

O'Brien, Eoin (1986), The Beckett Country, London: Faber \& Faber.

O'Grady, Standish (1878), History of Ireland: Heroic Period, web upload: https://archive.org/details/historyirelandh01gragoog (accessed 1 February 2017).

Pilling, John (1997), Beckett Before Godot, Cambridge: Cambridge University Press.

Tucker and Nixon (2015), 'Toward a Scholarly Edition of Beckett's Critical Writings', Journal of Beckett Studies 24:1, pp. 49-56.

Van Hulle, Dirk (2011), The Making of Samuel Beckett's Stirrings Still / Soubresauts and Comment / what is the word, London: Bloomsbury.

Wills, Clair (2007), That Neutral Island, London: Faber \& Faber.

'RTÉ 1940s', Archives Exhibitions, RTÉ online: http://www.rte.ie/archives/exhibitions/681history-of-rte/684-rte-1940s/ (accessed 2 February 2017).

“abroad”, OED Online. April 2017. Oxford University Press. http://www.oed.com.idpproxy.reading.ac.uk/view/Entry/594?rskey=k7MiOG\&result=2\& is Advanced=false (accessed April 20, 2017). 